\title{
The Concept of the Patient's Autonomy: From the Vaults of Civil Law
}

\begin{abstract}
By Anatoliy A. Lytvynenko*
The concept of patient's rights itself was fairly known before the last four or five decades, and medical malpractice of all kinds made the aggrieved party to seek redress at a court; but no special legislation, apart from rare exceptions, has ever existed to anchor the patient's rights before the late 20th century. In the civil law tradition of the 20th century, especially its earlier decades, doctors could be held criminally or civilly liable for a wide variety of malpractice, including unauthorised medical intervention or divulgation of patient's information, though such provisions did not develop actual rights, were quite general in their nature, and were individually assessed by the courts in each case. Within in the gradual change in the doctrines of medical law, the term "autonomy", shaping the patient's right to decide what medical interventions could or could not be performed upon his body, intervened into the existing legal scholarship, which was later augmented with various issues, such as access to medical records of the patient, refusal of blood transfusion, participation in medical experiments, deciding upon end-of-life situations or relating to various reproductive law considerations, not always permitted by national law. Many of these rights are much older than the concept of patient's autonomy themselves, and have developed in the case law which itself has originated from lawsuits against doctors and hospitals for acts, being nearly obscure in the existing legal doctrine, such as unauthorised medical experiments. The given paper is aimed to discuss the academic development and overall gist of the patient's right to autonomy, as well as some of its early interpretations in civil law doctrine.
\end{abstract}

Keywords: patient's rights, medical malpractice, theory of law, medical law, patient autonomy, civil law.

\section{Introduction}

In the civil law doctrine, which is the engine of legal scholarship in Eastern and Central Europe, the concept of patient's autonomy is primordially built upon the relatively recent concept of patient's rights, which are generally represented as a source of positive law ${ }^{1}$, which is technically developed upon a Roman law-based concept of the will of the patient, presupposing his power and authority to control the process of treatment and the amount of treatment which is administered to the

\footnotetext{
*Doctoral student at Baltic International Academy, Riga, Latvia (Department of Legal Sciences); Doctoral student at the School of Law at the Robert Gordon University of Aberdeen.

Email: anat.lytvynenko@gmail.com

${ }^{1}$ Mainly a patient's rights law, i.e. the Latvian Patient's Rights Law of 2009: Pacientu tiesību likums, Latvijas Vēstnesis, 205, 30.12.2009
} 
patient, usually including the right to refuse $i^{2}$. The Czech approach to the modern right to autonomy mainly lies in the enlargement of the doctrine of informed consent, which is far not technical, but in the amplification of the patient's role in his treatment. As we may notice, the European legal scholarship is far not uniform in the views of the legal and historical-legal foundation of the right to autonomy some works directly address this concept to American legal cases or scholarship ${ }^{3}$. However, the bioethical principles are not always compatible with the principles of civil law, as civil law frequently leaves little space for a broad interpretation of legal norms, and the courts hardly ever account bioethical principles to be worthy of consideration while forming the legal position in certain legal proceedings. Moreover, patient's right to autonomy, as a legal category is much older than the actual terms were coined. In civil law, the patient's rights are based upon aged jurisprudence and legal doctrine, which declared that the body integrity of the patient is his inborn, and inalienable right, as the right to life (thus equating them) ${ }^{4}$, and the will of the patient is the key element for legitimate doctoral activity, which is illegitimate against, or without the will of the sick, which derives from various old time legal sources from customary law to criminal law ${ }^{5}$. The concept of body integrity in civil law jurisdictions is a transformation of criminal law notions on the consent of the victim, which is inapplicable in the course of legitimate treatment activity of the physicians and hospitals, which are, by custom, statute or a legal precedent, entitled to "breach" the body integrity of the patients for the needs of medical (frequently surgical) treatment; however, such are banned against the will of the sick person, but the assessment of the age of consent, the actual situation when the medical intervention took place is up to the court ${ }^{6}$. However, the autonomy of the patient was usually restricted by urgent cases and imperative necessity. For instance, French courts have established that the will of the patient would not matter in case of emergent treatment ${ }^{7}$, which was further upheld by Canadian courts in a similar shape, e.g. in the case of Marshall v. Curry ${ }^{8}$. In Continental Europe, the courts were quick to recognise the restrictions of the patient's right to autonomy by statutory obligations of the doctors to report the state (i.e. the police or healthcare authorities) concerning the people suffering from dangerous contagious diseases (such as smallpox, syphilis, cholera etc.) ${ }^{9}$, or implementing medical treatment against the patient's will or the will of his legal representatives ${ }^{10}$.

I suppose that there is no uniform position in legal scholarship concerning the timeline of the patient's autonomy. For instance, in Germany, the terms related to

\footnotetext{
${ }^{2}$ Mazure (2011) at 28-41

${ }^{3}$ Doležal (2019).

${ }^{4} 1902$ g. 19 novembra, Po delu doktora meditsyny Petra Modlinskago, 1902 Senata Kriminālā Kasācijas Departamenta Spr. N. 33, 1902 KKD p. 84, 87-88

${ }^{5}$ Oppenheim (1892). at 20-22

${ }^{6}$ In Sache des Karl Schulze, Strafgericht Kanton Basel-Stadt, Urt. v. 14.06.1882,

${ }^{7}$ See. the note in Dechamps c. Demarche, Cour d'Appel Liege.

${ }^{8}$ Marshall v. Curry, at 271-274

${ }^{9}$ Preußische Obertribunal, at 307-308

${ }^{10}$ See, for instance, the 1927 judgment of the Supreme Court of Czechoslovakian Republic: Nejvyšši soud Československé republiky, Rozh. ze dne 18. ledna 1927.
} 
it were coined by courts in the late 1970s and early 1980s, where the courts adjudicated case in respect with a patient's right to insight into his medical records ${ }^{11}$. Later on, the German and German-speaking scholars referred to this concept as a "personality right of the patient" (as an extension of right to privacy originally it was called "Persönlichkeitsrecht des Patienten") ${ }^{12}$. However, the prototype concepts, featuring the patient's right to body integrity could be spotted in German-language legal and forensic literature from the period of 1850-1900, using the same description of the late- $20^{\text {th }}$ century concept, though with much older terminology $y^{13}$. However, the medical and ethical literature of Germany operated with similar terms (to which I will turn below) back in the mid-19 century $^{14}$. The American and Canadian literature frequently correlates the given concept with medical malpractice litigation featuring "informed consent" and the case of Salgo in $1957^{15}$, in spite of the fact that the term "informed consent" in the sense of medical law was initially used in 1935 by a French court in relation to an unauthorised medical experiment using a then-novel method of aortography, causing the patient's death ${ }^{16}$. The legal texts by US and Canadian scholars started featuring the word "autonomy" in medical law in the 1970s in a wide variety of patient's rights. One of such early examples featured a discussion on a newly established Natural Death Act in $1977^{17}$. Through the years, it was related to the right to refuse medical treatment ${ }^{18}$, confidentiality of medical records ${ }^{19}$, end-of-life decisions for legally incompetent patients, patient's informed consent and the patient's participation in biomedical research ${ }^{20}$. It is quite complicated to determine where patient's autonomy ends, especially upon the consideration of impossibility of, for instance, passive euthanasia (or even right to a dignified death - not involving a lethal drug or a judicially sanctioned life-support turndown), lacking a firm legal basis - otherwise, a similar decision would have to be implemented by the court upon substantial evidence affirming the patient's hopeless state, despite the fact his real will was not precisely known ${ }^{21}$. If we sum up all the fragmentons in a monolith, the right to autonomy usually means the

\footnotetext{
${ }^{11}$ OLG Bremen, 31.07.1979; BGH, 23.11.1982.

${ }^{12}$ Deutsch (1992).

${ }^{13}$ Oppenheim (1892) at 33-38; Grassl (1894) at 443-450.

${ }^{14}$ Braun (1853) at 419-422.

${ }^{15}$ Salgo v. Leland Board etc. Trustees.

${ }^{16}$ Cons. Chavonin c. Dr. L..., Admin. de l'Assistance Publique et Soc. de laboratoires Thorande; appeal: L. c. Consorts Chavonin et Cie des produits chimiques de la Sorbonne.

${ }^{17}$ Steinberg (1977). The term "patient autonomy" in the earlier years was also referred to in the sense of his right to refuse treatment, especially in connection with end-of-life issues, see. Jackson \& Younger (1980). Seemingly, the concept (at least its American or Canadian version) was initially strongly tied with issues of passive euthanasia, which became a subject of litigation in the 1970s.

${ }^{18}$ Hasl (1989). Hasl held that the right to autonomy derives from the right to bodily integrity, but is subject to a number of limitations, which were borne in the jurisprudence of the courts, primarily within the balance of the State's interest to preserve life, the private interest, and protecting the interests of the third parties. Satz v. Perlmutter (1980).

${ }^{19}$ Loughrey (2005).

${ }^{20}$ See., for instance, Brazier (1987); LoBiondo (1991).

${ }^{21}$ Accord the judgment of the Supreme Court of Justice of the Nation of Argentine in the case of Marcelo Diaz (2015): D., M.A. s/Declaración de Incapacidad. (see the court's justification of approving the decision to terminate life-support).
} 
patient's right to decide concerning medical treatment, and protest against medical interventions that are undesired. As of the outstanding US legal scholarship, the patient autonomy is be understood as a legal principle of the patient's protection against the encroachment of his legal right to participate in [medical] decisions, which somehow affect his life, and obviously, his health. The principle of autonomy is a weighty counterpart to a paternalistic model of legal-ethical relationships between patients and physicians ${ }^{22}$. The boundaries of this legal interpretation heavily rely upon legislation and jurisprudence of the country, and these may be incompatible with one another depending on the jurisdiction ${ }^{23}$.

\section{The Main Body}

Each of the rights embracing the right to autonomy is substantially older than the day it was tied to the overarching concept of "right to autonomy". However, did the right to autonomy have any progenitors bearing the same legal context, but probably a different name? Yes, it apparently did. Mostly the right to autonomy is associated with informed consent to treatment, or occasionally medical experiments $^{24}$ - and it was historically the first interpretation of it. The issue of consent to medical treatment could occasionally be spotted in the old-time medical books as well:
"A three-year-old son of a train machinist had a tonsil abscess. I told the [boy's] parents what was the matter, and proposed to cut through the abscess.
- So, what [do you mean], to cut through [the abscess], right in the [child's] mouth? - asked the mother, widely raising the eyebrows.
I explained, that the operation was completely harmless.
- Well, no! I do not have consent for this! - swiftly and decisively told the mother.
All my persuasions and explanations were in vain. [...]
- I think, it's the God's will for this [for the probable death of the child]. Wouldn't the God desire - it would be useless to cut through [the abscess] - [he] would die anyway. How would he, [being] so weak, survive the operation?" (the boy actually survived the operation and his condition of health gradually improved). ${ }^{25}$

In the 1930s, one Canadian author, MacDonald, speaking on Marshall v. Curry, one of the leading Canadian cases on informed consent, claimed that the

\footnotetext{
${ }^{22}$ Pellegrino (1994).

${ }^{23}$ For instance, see an American judgment from the state of Colorado, where an incapacitated person impugned a court order authorizing his guardian, the Morgan County Department of Human Services to execute a "do-not-resuscitate order" on his behalf (judgment of the lower court authorizing the "do-not-resuscitate-order" affirmed, People ex rel. Yeager. Such judgments show how much may the "autonomy" bend in different ways, including surrogate decisions on end-of-life issues. Besides, similar procedures do not exist in most of the civil law states and cannot be recognised by the courts on basis of acting civil law, family law or guardianship law. For instance, check my comment upon the characteristics of the patient's "living will" and its possible application in the civil law system: A. A. Lytvynenko (2021b).

${ }^{24}$ Oppenheim (1892) at 33-38.

${ }^{25}$ Veresaiev (1901)
} 
issue of patient's autonomy (in the shape of consent to medical treatment) was nearly undiscovered in both medical and legal literature, and the authorities (seemingly speaking about the English law) were nearly silent towards this question $^{26}$. It reminds Otto von Gierke's statement on the right to privacy in Roman law, which was either unrecognised, or undesired by the citizens ${ }^{27}$. As he spoke about the particular issue in German law, I conducted an archival search of authorities, contemporary to Gierke, or older than his works, and the result showed that they definitely existed ${ }^{28}$. The same could be claimed about case authorities, which could serve as a precedent to Canadian law in this respect, coming out from France $^{29}$, owing to the nature of Canadian legal system combining English common law and French civil law routes. However, materials on the patient's consent could be found in diverse medical and legal literature far before the authorities, cited by MacDonald (1933) occurred. Let us review and comment upon some of them.

E. Bouisson discussed the issue of patient's consent in respect with the administration of anaesthetics, such as chloroform, which came into a widespread use among surgeons in the 1840s: "The consent of the patient is necessary; if he refuses, the surgeon should attempt to persuade him, that he [the patient] deprives himself of a considerable advantage [of being etherised]; and if he [the patient] insists on refusal, he [the patient] should never be subjected to etherisation against his [will], unless it is a child"30. Administering anaesthetics was novel those days and was experimental to a certain extent, and thus, Bouisson found that it would ethically (and probably, legally as well) correct to ask the patient's consent before using it. The Antiquaille Hospital Case (trial of Guyenot and Gailleton) ${ }^{31}$ was one of the early informed consent cases in which the necessity of patient's consent was not only discussed by a court, but also in academic literature ${ }^{32}$. A boy, suffering from ringworm, was experimentally treated by an inoculation of a mucoid plaque, and the method was later described in a scientific journal; the doctors in charge were prosecuted and fined for an unconsented operation, which was apparently dangerous for the patient, made without consent, and entirely in the name of science $^{33}$. One of the defendants, when questioned, spoke about the issue of patient's consent, finding it illusory: "This [patient's] consent is in reality illusory; the patient of a hospital will always consent to what will be proposed to him, without being able to calculate the consequences; let him confide in the science of

\footnotetext{
${ }^{26}$ As for the case, see Marshall v. Curry at 271-274. As for the MacDonald's comment, see Macdonald (1933).

${ }^{27}$ von Gierke,(1895).

${ }^{28}$ Lytvynenko (2021a).

${ }^{29}$ See, for instance, Demarche c. Dechamps. Next, a few other judgments could be named: Chini $c$. Coconni, Trib. de. Aix, 22 October 1906, Dall. Per. 1907 II 41, 43; Bours c. Consorc Prevost, Trib. de Amiens, 14 Fevr. 1906, Dall. Per. 1907 II 44, 45; Epoux N c. Docteur Lenormant, Cour d'Appel de. Paris, 28 Juin 1923, Dall. Per. 1924 II 116, p.p. 116-117; Vve Seignobos c. Docteur H., 31 octobre 1933, Cour de Cass., 1934 Sirey I 11, 11-12.; Dr X c. Teyssier, 28 janvier 1942, Cour. de Cass, Cham. civ., Dall. Per. 1942 I 63

${ }^{30}$ Bouisson (1850).

${ }^{31}$ Min. Publ. c. Guyenot et Gailleton, Trib. corr. de Lyon.

${ }^{32}$ Martin-Lauzer (1860); Boucard (1860).

${ }^{33}$ Trib. corr. de Lyon, 15 dec. 1859, Dall. Per. 1859 II 87, 87-88
} 
the doctor". Mr. Royer, the Imperial Advocate, did not agree with this point of view $^{34}$. Deliberations of the case could be found in Boucard's brochure on the trial, making it practically the first medical-legal source to discuss the patient's autonomy in relation with medical experiments ${ }^{35}$. Many decades after, various French authors paid attention on the judgment itself, as well as on the principle of patient's autonomy, though not calling it directly by the name. For instance, Rene Demogue (1932) spoke concerning the liability of physicians, whose acts involving a dangerous medical intervention, were not aimed at curing the patient, but rather "removing a physical imperfection". He said: "It is still the same if the physician indulges in hazardous [clinical] trials, not to cure, but for the purposes of study [i.e. research]"36. This position was already adopted by the courts in cases, where plastic surgeons did unauthorised manipulations on people explicitly for the needs of scientific research, the results of which were published in scientific editions, or photographic exhibitions, and the medical intervention was barely, or completely unjustified from the view of curative goals ${ }^{37}$.

The necessity of obtaining the patient's free consent, including the explanation of the gist of the procedures to him also found its place in old time French literature on surgery. One of such earlier monuments could be found in Velpeau's book on clinical surgery, published in 1840 . He claimed: "Our duty is to show men [patient] what best [treatment] suits [curing] their ailments, to enlighten them on the dangers to which they expose themselves by not submitting [to treatment] [...] They still have the right to do, or not to do, what we advise [them]. It is otherwise with children and madmen, because not having their free will, fearing only [physical] pain, they do not know how to escape the dangers of the future $[\ldots]^{, 38}$. Guyon upheld this approach in his treatise on clinical surgery, where he discussed the patient's consent and will in respect to surgery as a preparatory stage of the operation, outlining the patient's will and consciousness in the necessity of the operation as an essential element for performing interventions into the patient's body, claiming that it is the doctor's duty to inspire the patient for undergoing the operation, giving him necessary confidence:

"When the patient is aware that everything [concerning the future surgery] has been discussed and weighed, that nothing that concerns his interests has been neglected, it is most often not difficult to make him understand the need for the operation..."

Later on, Guyon proceeds as to the strict obligation of obtaining the patient's consent before performing a surgery:

"It is indeed essential to obtain the patient's free consent before performing an operation. There can be no exception in this regard except for children whose will

\footnotetext{
${ }^{34}$ Editorial (1859).

${ }^{35}$ Boucard (1860).

${ }^{36}$ Demogue (1932).

${ }^{37}$ R.... c. P...., Cour d'appel de Lyon.

${ }^{38}$ Velpeau (1840).

${ }^{39}$ Guyon (1873).
} 
must be substituted by the will of the parents, and for the insane whose interests are represented by their families" ${ }^{\prime 4}$.

Upon these texts, it seems that French medical science has well recognised the principle of respecting the patient's will and autonomy, not mentioning these terms as such. So, the medical texts, as referred by MacDonald (1933), in fact, definitely had something to say concerning the will of the patient. In German medical literature and books on medical ethics, the term "Wünsch des Kranken" (i.e. "will of the patient") was occasionally spotted in the works of the XIX century, i.e. in Dr. Braun's treatise regarding the liability of physicians in 1853 . He discussed the question of conducting surgical operations with a certain degree of lethality, denoting that the mere will of the patient to undergo it should not serve as a mere indication for it. However, in these terms, the will of the patient was discussed in the view of his wish to undergo a certain substantial surgical operation, but not really speaking about his consent to it, as it was already presumed ${ }^{41}$. In the early to mid-XIX century, the legislation of the Prussian states regarding the treatment of the poor citizens on move (as well as the journeymen, craftsmen on the way to their point of destination etc., the following passage as to whether the sick would be able to proceed with his journey: "In all such cases the patient's own wish is only to be taken into account insofar as the doctor finds it useful"42. This provision was apparently narrow and was not intended to cover the issue of patient's autonomy in a general sense to consent to operations, or to request his medical records, or any similar thing, which is common nowadays.

Another branch of early interpretations of the patient's right to autonomy comes from Eastern and Central Europe. Quite a lot was said about the case of Dr. Modlinskiy (1902), who decided to cut out a tumour on an 18-year-old girl's abdomen without her consent, despite she and her family entered his clinics in order to remove a neck tumour, and the patient died after the laparotomy, which was a very dangerous operation with a high mortality risk at the dawn of the $20^{\text {th }}$ century. Dr. Modlinskiy was prosecuted and was convicted, his final appeal was dismissed by the Criminal Cassational Department of the Russian Governing Senate in November 1902: he was convicted of causing death by negligence while performing legal activity - i.e. conducting his work as a surgeon (Art. 1468 of the Criminal Code of 1885$)^{43}$. The surgeon was not claimed to have done the

\footnotetext{
${ }^{40} \mathrm{Ibid}$.

${ }^{41}$ Braun (1853).

${ }^{42}$ In original (German): "Der eigne Wunsch des Kranken ist in allen solchen Fällen nur insoweit zu berücksichtigen, als der Urzt dieß thunlich findet”. See, for instance,

1) Verordnung vom 16. Mai 1832, die Behandlung armer, auf der Reise begriffener Kranken betreffend, Art. 4, Codex Saronicus. Chronologische Sammlung der gesammten praktisch gültigen Königlich Sächfischen Gesetze von den älteften Seiten, vom Jahre 1255 an bis zum Schlusie des Jahres 1840; mit einem alphabetisch syftematischen Repertorium von Dr. jur. Wilhelm Michael Schaffrath. 3 weiter Band enthaltend: die gesammten Gefeße vom 9. März 1818 an bis zum Schlufie des Jahres 1840 / Leipzig, 1842, Bd. 2, S. 466-467

2) Geseß über das Heimathsrecht und das Armenwesen vom 9ten August 1833, Repertorium der Gesetz-Sammlung für das Herzogthum Altenburg: auf das Jahr 1833 (Nr.34), Nummer 1 bis Nummer 56 Art. 132 (2) / Alternburg, 1833., S. 161

${ }^{43} 1902$ g. 19 novembra, Po dielu doktora meditsyny Pietra Modlinskago.
} 
operation recklessly - negligence was affirmed in respect of defendant's failure to obtain the patient's consent. A number of medical and legal books featured discussion on the patient's will and its actual scope. For instance, Shyriaiev (1903) discusses the patient's autonomy in the light of the doctor's legal right to exercise his profession, and the patient's consent, upon him, is the pre-requisite to conduct it; at the same time, he addresses much attention on real-life situations, upon which it is either impractical to ask the patient's consent owing to various circumstances, or there may be emergent conditions, under which the doctor acts upon the presumed consent of the patient ${ }^{44}$. The court, in fact, took it into consideration, and Shyriaiev claimed that the case of Dr. Modlinskiy provided a general principle on the will of the patient, and it could be questionable, how could that be applicable under more specific circumstances, and the assessment of the doctor's judgment to act requires a thorough examination of the facts by courts ${ }^{45}$. He also acknowledged, that the doctors could be held liable of battery, acting without authorisation, even if the operation was necessary, though not strictly urgent ${ }^{46}$. He also emphasised that the judgment made a number of physicians to abstain from conducting operations without the patient's consent (real-life situations described by him frequently involved minors), which caused a multitude of deaths (but in fact, all situations described by him were urgent in general) ${ }^{47}$. He concludes: "All of the [aforementioned] indicates, that it is impossible to set up the patient's consent as a circumstance that has got a decisive significance for justifying the doctor's legitimate activity, not speaking of the [allegation], that the physician, if we set the question forth in such a mode, could be compared with an offender, making injuries under some dark motives, and justifying his acts under the request of the victim" 48 .

S. Tregubov (1904), one of the doctrinal commentators discussing the issue of patient's consent to medical treatment, observed different approaches to the legality of the doctor's activity, including conducting unconsented operations. As Shyriaiev (1903), he also starts his theory upon the legitimacy of the doctor's acts, as such, coming up with a conclusion that the prerequisites of consent in criminal law are not always technically applicable to the sense of legitimate activity of the physician, and if applied in whole, the doctors would frequently break the law on such occasion. So, his views were the following:

1) Consent should be a result of cognitive decisiveness, and thus, the consented party must be legally competent. Therefore, consent made by a legally incompetent person, or a minor, is void.

2) The legal competence should exist objectively, a mere allegation that the party (i.e. the patient) is competent is not enough.

3) The consent should be given freely, and a coerced or fraudulently obtained consent is void.

\footnotetext{
${ }^{44}$ Shyriaiev (1903).

${ }^{45} \mathrm{Ibid}$, at $18-23$

${ }^{46} \mathrm{Ibid}$, at 13-14, referring to: Reichsgericht, III Strafsenat, Urt. v. 31.05.1894.

${ }^{47} \mathrm{Ibid}$, at $23-24$

${ }^{48}$ Ibid, at 24
} 
4) The consented party should have some rights upon the thing he refuses;

5) The consent should be given before, or within committing an act, which makes it distinct from forgiveness;

6) The consent should have a definite character - that is, to be applied to certain time and acts, and is void being revoked.

Tregubov argued that the rule of the patient's will seemingly does not end with the operations, which are potentially dangerous to his health, but to merely any medical interventions. He also recalled a case, where a worker opposed to a hand amputation (as a result of a working accident), and the medical society found it would be incorrect to do anything against the patient's will (the event happened in 1885), he comes to the following conclusion:

1) As it follows, the doctor's activity, the lege artis, being itself not an illegal activity - is illegal, in case it violates the interests safeguarded by the legal norm, one of which is closely connected to the doctor's activity, is the everyone's right to freely use one's own personality"

2) So, as it follows [from the aforesaid], the doctor's activity, the lege arties, in case it is conducted upon the will of the patient, is not criminally punished regardless of the results, and reverse, the doctor's activity [conducted] against a clearly expressed will of the patient bears the elements of a criminally-punished offence against freedom of personality" 49 .

An anonymous Latvian lawyer named K.V. (1932) discussed the issue of the patient's autonomy, a yet unresolved issue in Latvian criminal law in the First Period of Independence ${ }^{50}$, making his conclusions mainly on basis of the 1902 case of Dr. Modlinskiy, which was generally known among early medical law scholarship of Eastern Europe in the first decades of the $20^{\text {th }}$ century. Like Shyriaiev (1903), he also attributed his basis of analysis on the bounds of the doctor's right to exercise his profession, whereas the patient's will be the foremost predisposition to conduct it. Here are his conclusions in a concise form:

1) 'If there is no obligation to submit to a doctor' prescription, then the doctor's right to perform the operation cannot be recognised without the patient's consent or permission expressed in this way or presumed on sufficient grounds";

\footnotetext{
${ }^{49}$ Tregubov (1904).

${ }^{50}$ The books reporting the Latvian Senate's judgments on medical malpractice or crimes committed by doctors (i.e. abortions done illegally) do not contain cases in respect with unconsented operations. However, the case report of the trial of Dr. Londenberg (1926) mentions that an allegedly illegal abortion was made upon the pregnant woman's firm consent. However, the case fell apart owing to insufficient evidence, as it was clearly established neither when the abortion took place, nor what was the actual state of health of the mother and the health/life of the fetus. See: 1926 g. 28 sept. spr. Londenberga 1. Nr. 537, Latvijas Senata Kriminālā Kasācijas Departamenta spriedumu tezu pilnigs kopojums, no. 1919 g. lidz. 1928 g. 31 decembrim (1928) // F. Kamradziuss, p. 306-309; see additionally: 1928 g. 30 marta spr. Sternbergs 1. Nr. 124, 1919-1928 Kopojums, Lieta No. 592, p. 311.
} 
2) "By turning to a doctor for help, the patient does not lose the right to get use of his or her personal, natural rights and does not become available to the doctor in full, even though the doctor has acquired the privilege of treatment on the basis of his or her knowledge" $" 51$.

3) Now, concerning the cases of an emergency: "There is no doubt that in such cases, when a patient is in a very difficult condition and unconscious, in the absence of relatives, there will be obstacles to obtaining permission for the operation, which, according to the doctor, is necessary to save his life. In such cases, of course, the doctor may presume the existence of a permit."

4) Concerning the extension of the surgical operation: “...at the time of removal of an operation for which the consent of the patient or his/her relatives was obtained, it turns out that additional surgery is required in another organ or in other amounts, the authorisation shall be presumed"52.

Concerning Latvian law in this respect, I should denote that K.V. was likely to be right in respect with the fact that unconsented medical interventions were barely, or completely unknown and thus unresolved in Latvian criminal law. What is more, in 1933, the Criminal Code was augmented with Art. 218, punishing an unconsented medical intervention from the side of the doctor ${ }^{53}$, but no liability for an unauthorised medical intervention existed priorly to the enactment of the said provisions. A custom search in the funds of Latvian State Historical Archive (mainly upon the funds of the Riga regional court, Riga Chamber of Justice ${ }^{54}$ and the Senate of Latvia) revealed that the criminal investigations, lodged mainly upon a complaint the aggrieved party (and frequently, the person joined the proceedings as a civil plaintiff) considered medical negligence (i.e. Art. 219 of the Criminal Code), but the content of the cases revealed that it hardly ever dealt with the question of the patient's will ${ }^{55}$, apart from the fact of the necessity to undergo treatment. For instance, a factory worker from Sloka ${ }^{56}$, who was suffering from a toothache, decided to undergo dental treatment in the clinics of a stomatologist, who was known not only for cheap services, but for horrible attitude to dental caution, unwilling to sterilise surgical equipment, and was considered to be negligent and careless by his patients. The patient's will to receive the services of the said doctor only brought to the deterioration of his dental health, resulting in an in-patient treatment at a hospital; during the proceedings, brought by the factory worker, the doctor died ${ }^{57}$. Another example is the case of Gržibovsky, who was

\footnotetext{
${ }^{51}$ K.V. (1932).

${ }^{52}$ Ibid.

${ }^{53}$ Ārsta atbildība pēc 1933.

${ }^{54}$ A "Chamber of justice" (Latvian "Tiesu palata") is a term for an appellate court in the period of First Independence of Latvia (1918-1940). At present time, they are renamed as "Apgabaltiesa", or a "Regional court" in English.

${ }^{55}$ See, for instance, Kovalenko pret. Dr. Akerman, (case relating to a complaint of a prisoner, who was suffering from sciatica, against a doctor, who, upon his view, was negligent towards his health condition).

${ }^{56}$ Currently a part of Jurmala.

${ }^{57}$ Ziberg pret Dr. Adamson.
} 
unfortunate for his leg to be overrun by a bus, and the doctors of the hospital twice declined to accept him. When he arrived to another hospital, the doctors suggested that the leg requires amputation, though the patient refused, but was later hospitalised and lost his leg owing to a developing gangrene. The fact of the patient's refusal was mentioned by the defendant's counsel, however the courts found that the development of the gangrene was not a consequence of his refusal, but a consequence in a delay in his medical treatment, which began since plaintiff was refused to admitted to the hospital and thus he prevailed in action against the city $^{58}$. These two cases, as well as similar ones (the funds contained around 20 cases on medical malpractice, including criminal cases on rude hospital negligence and omission to provide medical assistance) tended to demonstrate, that the question of the patient's will was seemingly observed only in the shape his will to obtain treatment, but not his choice of the doctor, or treatment methods, or anything that could shape the patient's autonomy.

Another segment of early interpretations of the right to autonomy goes to the German-speaking literature. The two scholarships I would like to point out are a legal scholar from Basel, Oppenheim (1892), probably one of the first ones to deal with the issue of the patient's autonomy, and J. Grassl, MD (1894), who had dealt with the problem of defining the responsibility of physicians as such, overviewing the existing case and the outstanding medical practice. Grassl has discussed the responsibility of physicians in general sense, including liability for unconsented medical interventions and medical experiments, underlining the necessity of the patient's consent, citing the case resolved by the German Supreme Court in 1894, as well as a case concerning a man's confinement to a psychiatric asylum on basis of his family's hatred and a superficial medical report. As Oppenheim held earlier, he affirmed that unconsented experiments on patients are impermissible ${ }^{59}$; what is more, both Grassl (1894) and Oppenheim (1892) speak about the legitimacy of such acts upon "common law", though through the years, it is not clear whether they mean it was established by judicial precedent (in fact, Oppenheim reports such decision from the Basel criminal court adjudicated in $1882^{60}$ ), or it was really an "unwritten" norm, and only an ethical consideration (i.e. similar to the views of Velpeau (1840) and Guyon (1873) - the former wrote his treatise before the Antiquaille Hospital Case, and nothing indicated that the latter founded his considerations upon the so-called "Antiquaille Hospital case"). L. Oppenheim (1892) connected the patient's will to the issue of consent to medical experiments. Upon his considerations and real-life situations, he observed, he came to the following conclusions:

\footnotetext{
${ }^{58} 1937$ g. 25 nov. / 16 dec., Vacslava Gržibovska prasībā pret Rīgas pilsētu v. c. summā Ls 14.097, Senāta Civilā kasācijas departamenta, Pašvaldības Balls, No. 7(01.07.1939); Pašvaldību Darbinieks, Nr. 4 (01.04.1939) (Case No. 10). No other marking or reporting of this case was found in the archives, except from the two given newspapers, which reported court judgments and other news relating to Riga municipality and issues relating to workers and worker rights.

${ }^{59}$ Grassl (1894).

${ }^{60}$ Oppenheim (1892) at 42-45.
} 
1) Many medical experiments were conducted without patient's consent, though it is apparent, that progress in medicine is impossible without experimental ways of treatment.

2) No medical experiments are allowed without the will of the patient - both on people being healthy, ill, or even being sentenced to death. Oppenheim cited a number of real-life situations, where the experimental methods of treatment were both positive and deplorable.

3) Even if these dangerous medical experiments were conducted with the consent of the patient, the doctors were usually punished for bodily harm.

A Belgian advocate named Tart (1894) observed the issue of the patient's will to medical interventions, and was also critical in respect with experimental treatment, though did not deny it as completely illegal. "A doctor never has the right to carry out experiments upon his patient. By [claiming] this, I mean that any experimental research for the purposes of curiosity or for scientific interest - is strictly prohibited. The interest in the patient's health is the measure of both is rights and his duties. The doctor's exclusive mission is to try to heal [the patient]; any act, which goes beyond this limit becomes immediately illegal, and must be repressed". He upheld the view that experimental means of treatment could be justifiable, in case they are applied in order to save the patient's life, which is apparently a plausible goal ${ }^{61}$. The aforesaid principle was well applied by the civil court of Seine in the case of Chavonin, and reiterated by the Paris Court of Appeals (1935-1937).

\section{Assessment by the Courts}

Occasionally, the gist of the patient's right to body integrity (those days, it was referred to as such) was expounded by courts themselves on basis of general principles of civil and criminal law, as well as by the commenters of the court judgments in official court reports (for instance, in France), which have become "memorials" for further development of medical law. As I will show in the comments and the table of the most notable judgments below, the courts in the civil law systems have developed the maxims for establishing the patient's right to express his will concerning his medical treatment at least not later that the courts in common law systems.

\footnotetext{
${ }^{61}$ Tart (1894).
} 
Table A. Below Provides for the most Outstanding Jurisprudential Legacy in the Continental Legal System

\begin{tabular}{|c|c|c|c|c|}
\hline Year & $\begin{array}{l}\text { Name of the } \\
\text { case }\end{array}$ & Court & $\begin{array}{l}\text { Summary of the } \\
\text { case facts }\end{array}$ & $\begin{array}{c}\text { Summary of the } \\
\text { judgment }\end{array}$ \\
\hline 1856 & $\begin{array}{l}\text { Carl Joachim } \\
\text { Christian } \\
\text { Bracker, Klager, } \\
\text { gegen Dr. Juris } \\
\text { Albrecht, mand. } \\
\text { nom }\end{array}$ & $\begin{array}{l}\text { Oberappellationsgericht } \\
\text { zu Lübeck }\end{array}$ & $\begin{array}{l}\text { A doctor ordered a } \\
\text { wet nurse to feed a } \\
\text { baby with } \\
\text { congenital } \\
\text { syphilis, as a result } \\
\text { of which the } \\
\text { woman and her } \\
\text { family contracted } \\
\text { the disease. The } \\
\text { doctor had not } \\
\text { informed the } \\
\text { woman that the } \\
\text { baby was ill. }\end{array}$ & $\begin{array}{l}\text { The highest court } \\
\text { of Lubeck found } \\
\text { the doctor liable } \\
\text { for professional } \\
\text { negligence. }\end{array}$ \\
\hline 1859 & $\begin{array}{ll}\text { Min. Publ. } & \text { c. } \\
\text { Guyenot } & \text { et } \\
\text { Gailleton } & \end{array}$ & $\begin{array}{l}\text { Trib. corr. de Lyon } \\
\text { Criminal Court of Lyon }\end{array}$ & $\begin{array}{l}\text { Two doctors } \\
\text { treated a minor at } \\
\text { the Antiquaille } \\
\text { Hospital of Lyon } \\
\text { from ringworm. } \\
\text { They used an } \\
\text { inoculation of } \\
\text { syphilis for } \\
\text { treatment. } \\
\text { However, they } \\
\text { conducted the } \\
\text { inoculation for the } \\
\text { necessity of } \\
\text { conducting an } \\
\text { experiment, } \\
\text { having published } \\
\text { the outcome in a } \\
\text { scientific article. } \\
\text { The procedure was } \\
\text { done without the } \\
\text { authorisation of } \\
\text { the boy's parents. }\end{array}$ & $\begin{array}{l}\text { The doctors were } \\
\text { found to be guilty } \\
\text { of battery (Art. } \\
319 \text { and } 320 \text { of } \\
\text { the French } \\
\text { Criminal Code), } \\
\text { and were fined } \\
\text { for their } \\
\text { misdemeanour. } \\
\text { The court } \\
\text { concluded, that } \\
\text { even an } \\
\text { inoculation the } \\
\text { without thents consent } \\
\text { patient's colls to a battery. } \\
\text { tollo }\end{array}$ \\
\hline $\begin{array}{l}1889- \\
1890\end{array}$ & $\begin{array}{ll}\text { Demarche } & \text { c. } \\
\text { Dechamps } & \\
\text { Dechamps } & \text { c. } \\
\text { Demarche } & \end{array}$ & $\begin{array}{l}\text { Trib. civ. de Liege } \\
\text { Cour d'Appel Liege }\end{array}$ & $\begin{array}{l}\text { An infant was } \\
\text { brought for a leg } \\
\text { curvature } \\
\text { correction to the } \\
\text { clinics of Dr. } \\
\text { Dechamps in } \\
\text { Liege. The doctor } \\
\text { decided to perform } \\
\text { an osteotomy, } \\
\text { despite it was } \\
\text { seemingly not } \\
\text { approved by those- } \\
\text { day medical } \\
\text { science to be } \\
\text { eligible to be } \\
\text { conducted to }\end{array}$ & $\begin{array}{l}\text { The trial court } \\
\text { upheld the father's } \\
\text { claim, but the } \\
\text { appellate court has } \\
\text { found that } \\
\text { nevertheless, the } \\
\text { consent from the } \\
\text { side of the family } \\
\text { was actually given, } \\
\text { as the doctor } \\
\text { managed po prove } \\
\text { it by witness } \\
\text { testimony, and in } \\
\text { this part, the appeal } \\
\text { would succeed. } \\
\text { However, the }\end{array}$ \\
\hline
\end{tabular}




\begin{tabular}{|c|c|c|c|c|}
\hline & & & $\begin{array}{l}\text { minors of his age. } \\
\text { The operation was } \\
\text { very unsuccessful, } \\
\text { which brought to } \\
\text { the amputation of } \\
\text { the child's foot. } \\
\text { Plaintiff, the } \\
\text { father, claimed } \\
\text { that the operation } \\
\text { was unconsented. }\end{array}$ & $\begin{array}{l}\text { doctor was found } \\
\text { to be negligent in } \\
\text { the care for the } \\
\text { child. Since both } \\
\text { acts (i.e. } \\
\text { negligence and an } \\
\text { unconsented } \\
\text { medical } \\
\text { intervention) were } \\
\text { treated by the court } \\
\text { as professional } \\
\text { negligence (Art. } \\
1382 \text { of the Civil } \\
\text { Code), there the no } \\
\text { seemed to be no } \\
\text { real difference in } \\
\text { the outcome }\end{array}$ \\
\hline & $\begin{array}{c}\text { g. W. Rep. } \\
1406 / 94\end{array}$ & Reichsgericht & $\begin{array}{l}\text { A 7-year-old girl } \\
\text { was brought to a } \\
\text { hospital, suffering } \\
\text { from tubercular } \\
\text { suppuration of her } \\
\text { tarsal bones. The } \\
\text { doctor attempted } \\
\text { to stop the } \\
\text { progression of the } \\
\text { disease by bone } \\
\text { resection, but the } \\
\text { father opposed the } \\
\text { operation, and said } \\
\text { he would desire } \\
\text { the girl to be } \\
\text { released from the } \\
\text { hospital. } \\
\text { Nevertheless, the } \\
\text { operation was } \\
\text { performed, the } \\
\text { doctor did not } \\
\text { succeed in it, and } \\
\text { the girl's foot was } \\
\text { subsequently } \\
\text { amputated. }\end{array}$ & $\begin{array}{l}\text { The doctor was } \\
\text { initially acquitted, } \\
\text { but the prosecution } \\
\text { and the father, as } \\
\text { civil plaintiff, } \\
\text { appealed. The } \\
\text { Reichsgericht } \\
\text { found the doctor } \\
\text { should be liable } \\
\text { under the charge of } \\
\text { battery (Art. 223 of } \\
\text { the Penal Code), } \\
\text { remanding the } \\
\text { case. The Court } \\
\text { found that after the } \\
\text { sane patient's (or } \\
\text { his legal } \\
\text { representative's) } \\
\text { refusal, the } \\
\text { doctor's authority } \\
\text { to treat expires. } \\
\text { The subsequent } \\
\text { legal notes } \\
\text { disclosed, that the } \\
\text { doctor was } \\
\text { acquitted when the } \\
\text { case was heard } \\
\text { before the lower } \\
\text { court again }{ }^{63} \text {. }\end{array}$ \\
\hline 1902 & $\begin{array}{l}\text { Po delu doctora } \\
\text { meditsiny Petra } \\
\text { Modlinskago }\end{array}$ & \begin{tabular}{lrr} 
Criminal & \multicolumn{2}{c}{ Cassational } \\
Department & of the \\
Russian & Governing \\
Senate &
\end{tabular} & $\begin{array}{l}\text { A young woman } \\
\text { came to a private } \\
\text { surgical clinics to } \\
\text { get rid of a tumour }\end{array}$ & $\begin{array}{l}\text { The doctor was } \\
\text { found to be guilty } \\
\text { under Art. } 1468 \text { of } \\
\text { the Penal Code }\end{array}$ \\
\hline
\end{tabular}

${ }^{62}$ The Dechamps case reports may vary in their text. The outcome was extracted from Dall. Per. 1891 II 281.

${ }^{63}$ Extracted from Decisions of the Reichsgericht in Criminal Cases, Vol. 25, p.p. 375 - 384 (Case No. 127). Officially: ERG St. Bd. 25, S. 375, 376-377; 380-384 (Sache No. 127). 


\begin{tabular}{|c|c|c|c|c|}
\hline & & & $\begin{array}{l}\text { on her neck. } \\
\text { During the } \\
\text { examination } \\
\text { defendant found a } \\
\text { bigger tumour in } \\
\text { her abdomen, } \\
\text { deciding to cut it } \\
\text { out as soon as } \\
\text { possible, without } \\
\text { the girl's, or her } \\
\text { parents' consent. } \\
\text { The girl died } \\
\text { owing to } \\
\text { complexifications } \\
\text { of the laparotomy. }\end{array}$ & $\begin{array}{l}\text { (causing death } \\
\text { within legitimate } \\
\text { activity due to } \\
\text { negligence). The } \\
\text { court also held that } \\
\text { the operation was } \\
\text { not conducted } \\
\text { negligently, as } \\
\text { such. The } \\
\text { negligence of the } \\
\text { doctor lied in the } \\
\text { fact of conducting } \\
\text { a life-threatening } \\
\text { operation without } \\
\text { the patient's } \\
\text { consent. }\end{array}$ \\
\hline 1915 & Rv I 448/15 & $\begin{array}{l}\text { Oberster Gerichtshof } \\
\text { (Austro-Hungaria) }\end{array}$ & $\begin{array}{l}\text { Plaintiff suffered } \\
\text { from knock knees, } \\
\text { and applied to a } \\
\text { Vienna hospital in } \\
\text { order for a surgical } \\
\text { correction. } \\
\text { However, the } \\
\text { operation was not } \\
\text { very successful, as } \\
\text { plaintiff had bow } \\
\text { legs instead of } \\
\text { knock knees, } \\
\text { despite her general } \\
\text { condition became } \\
\text { much better, } \\
\text { allowing her to } \\
\text { work and conduct } \\
\text { household duties. } \\
\text { Plaintiff blamed } \\
\text { the doctors in } \\
\text { short, in negligent } \\
\text { treatment, and } \\
\text { inter alia, in not } \\
\text { properly informing } \\
\text { her on the } \\
\text { consequences of } \\
\text { the operation. }\end{array}$ & $\begin{array}{l}\text { The courts of all } \\
\text { three instances did } \\
\text { not find any } \\
\text { negligence from } \\
\text { the side of the } \\
\text { doctors owing to } \\
\text { expert conclusions. } \\
\text { Concerning the } \\
\text { duty to inform, the } \\
\text { Vienna Court of } \\
\text { Appeals said, that } \\
\text { the general duty of } \\
\text { the doctor to } \\
\text { inform the patient } \\
\text { does exist, but does } \\
\text { not include the } \\
\text { necessity to warn } \\
\text { about all the } \\
\text { existing } \\
\text { possibilities of } \\
\text { negative } \\
\text { consequences. The } \\
\text { Supreme Court } \\
\text { upheld } \\
\text { decisions of the } \\
\text { lower courts. }\end{array}$ \\
\hline $\begin{array}{l}1933- \\
1935\end{array}$ & $\begin{array}{l}\text { Cons. Chavonin } \\
\text { c. Dr. L..., } \\
\text { Admin. de } \\
\text { l'Assistance } \\
\text { Publique et Soc. } \\
\text { de laboratoires } \\
\text { Thorande } \\
\text { (I instance) } \\
\text { L. c. Consorts } \\
\text { Chavonin et Cie } \\
\text { des produits } \\
\text { chimiques de la }\end{array}$ & $\begin{array}{l}\text { Trib. civ. de la Seine } \\
\text { Cour d'appel de Paris }\end{array}$ & $\begin{array}{l}\text { Two interns were } \\
\text { conducting } \\
\text { biomedical } \\
\text { research in relation } \\
\text { to an aortography, } \\
\text { and sought for } \\
\text { someone who } \\
\text { could volunteer for } \\
\text { an experiment. A } \\
\text { doctor, who } \\
\text { treated a patient } \\
\text { from a vascular } \\
\text { disease a year }\end{array}$ & $\begin{array}{l}\text { The both trial and } \\
\text { appellate court } \\
\text { discovered that } \\
\text { there is a direct } \\
\text { causal link } \\
\text { between the } \\
\text { patient's death and } \\
\text { the injection of the } \\
\text { opaque. The court } \\
\text { stressed that } \\
\text { experimental } \\
\text { treatment with a } \\
\text { curative goal }\end{array}$ \\
\hline
\end{tabular}


Vol. 8, No. 1 Lytvynenko: The Concept of the Patient's Autonomy: From the Vaults...

\begin{tabular}{|c|c|c|c|c|c|}
\hline & $\begin{array}{l}\text { Sorbonne } \\
\text { (II instance) }\end{array}$ & & & $\begin{array}{l}\text { before, suggested } \\
\text { he knows such } \\
\text { patient. This } \\
\text { patient was about } \\
50 \text { years of age } \\
\text { and a factory } \\
\text { worker. He was } \\
\text { called by the } \\
\text { doctor, but the } \\
\text { actual aim of his } \\
\text { presence was } \\
\text { concealed. The } \\
\text { interns injected the } \\
\text { opaque to him, but } \\
\text { the man shortly } \\
\text { died thereafter. } \\
\text { The consorts sued } \\
\text { the doctor and the } \\
\text { hospital. }\end{array}$ & $\begin{array}{l}\text { should be } \\
\text { distinguished from } \\
\text { medical } \\
\text { experiments, } \\
\text { conducted for } \\
\text { research purposes. } \\
\text { The doctor was } \\
\text { found to be liable, } \\
\text { and he did not } \\
\text { strictly deny the } \\
\text { facts which } \\
\text { brought to the } \\
\text { patient's death. He } \\
\text { filed an appeal, } \\
\text { which was } \\
\text { unsuccessful. }\end{array}$ \\
\hline 1936 & $3 \mathrm{Ob} 984 / 36$ & $\begin{array}{l}\text { Supreme } \\
\text { Austria }\end{array}$ & Court of & $\begin{array}{l}\text { Plaintiff applied to } \\
\text { the court to } \\
\text { produce a copy of } \\
\text { her medical record } \\
\text { to sue the doctor, } \\
\text { who prescribed her } \\
\text { pills of which she } \\
\text { was poisoned, or } \\
\text { the pill } \\
\text { manufacturer, as } \\
\text { she was treated } \\
\text { from poisoning in } \\
\text { a sanatorium } \\
\text { priorly to the } \\
\text { lawsuit, and } \\
\text { thought that the } \\
\text { medical record } \\
\text { would be } \\
\text { sufficient evidence } \\
\text { for a future action. }\end{array}$ & $\begin{array}{l}\text { The Supreme } \\
\text { Court did not grant } \\
\text { an order for } \\
\text { production of } \\
\text { medical records. It } \\
\text { held, that medical } \\
\text { records are private } \\
\text { documents, and } \\
\text { cannot be produced } \\
\text { for the needs of a } \\
\text { private claim. } \\
\text { Instead, the court } \\
\text { held that plaintiff } \\
\text { could ask the chief } \\
\text { physician of the } \\
\text { sanatorium to } \\
\text { testify concerning } \\
\text { the necessary } \\
\text { details of her } \\
\text { medical treatment. }\end{array}$ \\
\hline 1937 & $\begin{array}{l}\text { Parties: } \\
\text { Bolesław M. M. } \\
\text { przeciwko } \\
\text { Uniwersytetu } \\
\text { Jagiellońskiego } \\
\text { w Krakowie i } \\
\text { dr. Mieczysław } \\
\text { O. } \\
\text { Official name of } \\
\text { the case: Sygn. } \\
\text { C.II. 885/37 }\end{array}$ & $\begin{array}{l}\text { Sąd } \\
\text { (Supreme } \\
\text { Poland) }\end{array}$ & $\begin{array}{l}\text { Najwyższy } \\
\text { Court of }\end{array}$ & $\begin{array}{l}\text { A physician and } \\
\text { the medical } \\
\text { institution were } \\
\text { sued by a patient } \\
\text { who was treated } \\
\text { from psoriasis by a } \\
\text { sulphur mustard } \\
\text { gas, which caused } \\
\text { the treatment to be } \\
\text { even longer and } \\
\text { more painful. }\end{array}$ & $\begin{array}{l}\text { The court found } \\
\text { that the physician } \\
\text { is subject for civil } \\
\text { liability in such a } \\
\text { case, if he does not } \\
\text { inform the patient } \\
\text { on the course of } \\
\text { experimental } \\
\text { treatment, and } \\
\text { general consent to } \\
\text { treatment is not } \\
\text { sufficient, the } \\
\text { physician is } \\
\text { obliged to give } \\
\text { details concerning } \\
\text { such "special" }\end{array}$ \\
\hline
\end{tabular}




\begin{tabular}{|c|c|c|c|c|c|}
\hline & & & & & $\begin{array}{l}\text { treatment. The } \\
\text { facts of the case } \\
\text { were not properly } \\
\text { established by the } \\
\text { Poznan Court of } \\
\text { Appeals, and the } \\
\text { Sad Najwyższy } \\
\text { remanded the } \\
\text { case }^{64} \text {. }\end{array}$ \\
\hline 1969 & $\begin{array}{l}\text { Min. Publ. c. } \\
\text { Fardeau, Slosse } \\
\text { et Leclerc }\end{array}$ & $\begin{array}{l}\text { Trib. corr } \\
\text { (Brussels } \\
\text { Court) }\end{array}$ & $\begin{array}{c}\text { Bruxelles } \\
\text { Criminal }\end{array}$ & $\begin{array}{l}\text { In 1967, a man } \\
\text { asked the doctors, } \\
\text { defendants in the } \\
\text { case, to perform a } \\
\text { gender } \\
\text { reassignment. } \\
\text { After a substantial } \\
\text { number of } \\
\text { consultations, they } \\
\text { decided to conduct } \\
\text { the operation, } \\
\text { changing his sex to } \\
\text { a woman, and thus } \\
\text { conducting a very } \\
\text { unusual operation } \\
\text { by the time of the } \\
\text { 60s. The patient, } \\
\text { however, died due } \\
\text { to pulmonary } \\
\text { embolism. The } \\
\text { criminal case was } \\
\text { opened owing to } \\
\text { an anonymous } \\
\text { report to the law } \\
\text { enforcement } \\
\text { agencies. }\end{array}$ & $\begin{array}{l}\text { The court decided } \\
\text { to acquit the } \\
\text { doctors. It was not } \\
\text { proven by the } \\
\text { prosecution, that } \\
\text { the doctors broke } \\
\text { the rules of } \\
\text { medical art while } \\
\text { conducting the } \\
\text { operation, or } \\
\text { provoked the } \\
\text { patient's death. } \\
\text { The operation was } \\
\text { fully consented, } \\
\text { and the patient was } \\
\text { well informed } \\
\text { about it, and was } \\
\text { happy to become a } \\
\text { woman. }\end{array}$ \\
\hline 1979 & $\begin{array}{l}\text { Parties: Alicja } \\
\text { M. przeciwko } \\
\text { Skarbu Państwa } \\
\text { (Zespó1 Opieki } \\
\text { Zdrowotnej dla } \\
\text { miasta } \\
\text { Częstochowa) } \\
\text { Official name of } \\
\text { the case: Sygn. } \\
\text { IV CR 389/79 }\end{array}$ & $\begin{array}{l}\text { Sąd } \\
\text { (Supreme } \\
\text { Poland) }\end{array}$ & $\begin{array}{l}\text { Najwyższy } \\
\text { Court of }\end{array}$ & $\begin{array}{l}\text { Plaintiff } \\
\text { underwent } \\
\text { treatment owing to } \\
\text { a cancerous } \\
\text { condition of the } \\
\text { cervix. In 1975, } \\
\text { she claimed to } \\
\text { have undergone an } \\
\text { operation, which } \\
\text { was performed } \\
\text { incorrectly. She } \\
\text { claimed, that as a } \\
\text { result of negligent } \\
\text { operation, she }\end{array}$ & $\begin{array}{l}\text { The Supreme } \\
\text { Court dismissed } \\
\text { the complaint. It } \\
\text { upheld the } \\
\text { principle, that the } \\
\text { doctors have an } \\
\text { obligation to } \\
\text { inform the patients } \\
\text { concerning various } \\
\text { complex treatment } \\
\text { and disclose the } \\
\text { main dangers } \\
\text { coming out of it, } \\
\text { but this does not }\end{array}$ \\
\hline
\end{tabular}

\footnotetext{
${ }^{64}$ Extracted from the Supreme Court of Poland Reports of 1938, copybook 6, Case No. 291, at p. 713 - 715. Officially: Zb. Orz. 1938, z. 6, poz. 291, s. 713

${ }^{65}$ Min. Publ. c. Fardeau, Slosse et Leclerc, Trib. corr. Bruxelles (22 ch.), 27 septembre 1969, Journal des Tribunaux Vol. 1969 (15.11.1969), No. 4676, p. 635, at p. 635-638; 639-641; also reported in Pasicrisie, Vol. 1969, p. III, p.p. 114-128.
} 


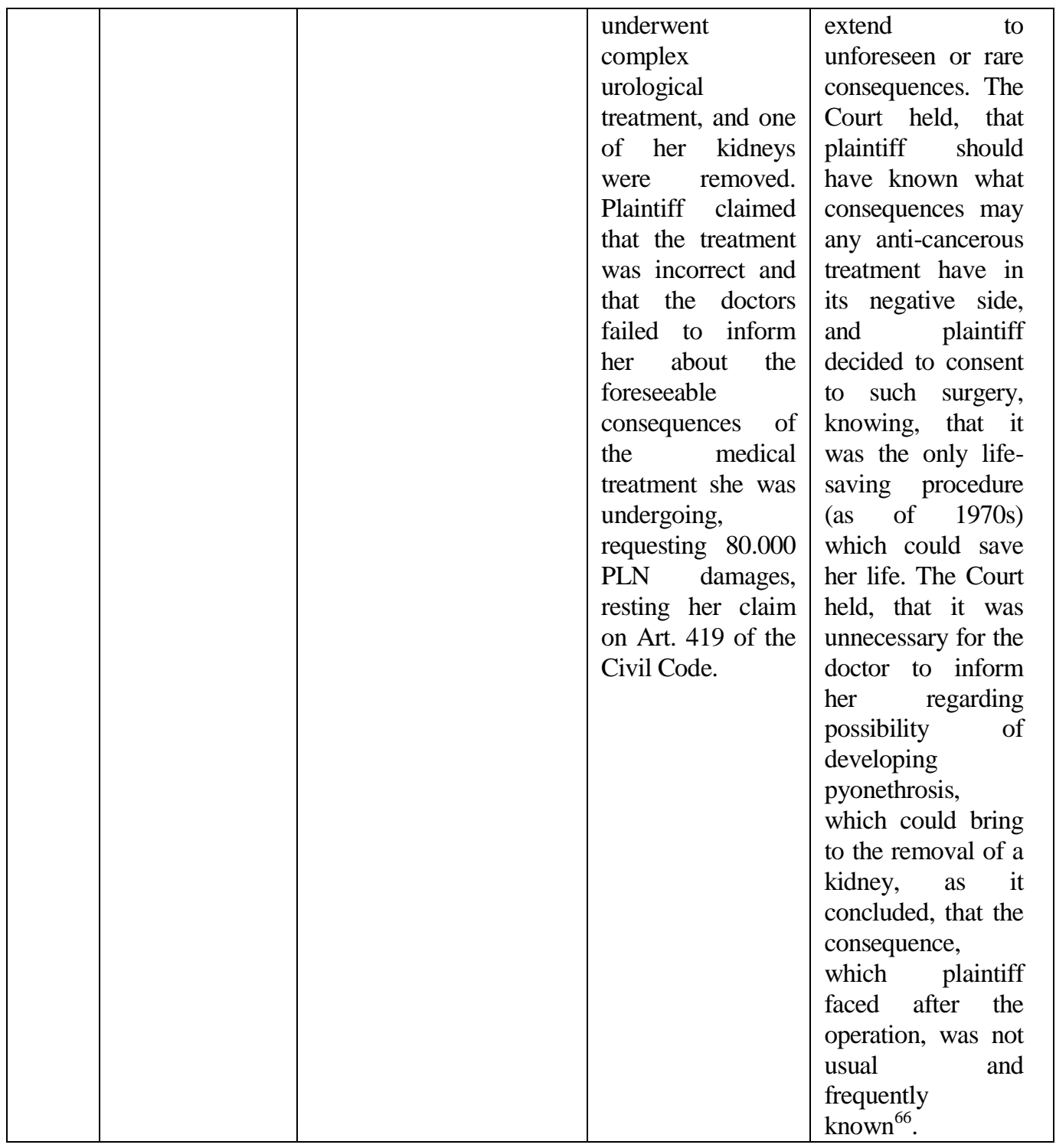

\section{Conclusions}

To sum up the material, provided in the paper upwards, the right to patient's autonomy could be synthesised as his right to be involved in the process of treatment by demonstrating his will, including the patient's right to abstain from subjectively undermanned medical interventions. The earliest concepts of patient's autonomy coming from Europe mainly were connected with legitimate boundaries of medical profession, the will of the patient and unauthorised medical experiments, and the treatises were often connected to resonant court judgments, not being written in abstract. At the same time, the principle of respecting the patient's autonomy and enlightening him in respect with future medical interventions, and

${ }^{66}$ Extracted from the Supreme Court of Poland Reports, Civil Cases, Year 1980, copybook 4, Case No. 81. Officially: OSNC 1980/4/81 
proving benefits for the patient, was well established not only in case law, but in medical literature as well, thus being adopted as an ethical principle and a legal prerequisite for legitimate medical activity. The right to autonomy has transformed into a multitude of shapes, but the core principle of respect for the patient's will remains the same in modern medical law, spanning to other rights of the patients, which became more significant in the late $20^{\text {th }}$ and early $21^{\text {st }}$ century, such as access to the patient's medical records or a right refusal of treatment. The latter ones were completely unknown before (i.e. the first cases relating to access to medical documents could be found in $1930 \mathrm{~s}^{67}$, and have spread since the 1960s), and the concept of the patient's will be mainly related to his or her will to undergo treatment or his consent to medical (mainly surgical) interventions. Thus, having researched on the foundations of the right to autonomy in legal and medical literature of the past centuries, it should be concluded, that the will of the patient in its contemporary legal sense was formed in the mid- $20^{\text {th }}$ century, and its early prototypes did not really reflect his actual involvement into the process of treatment and decision-making, with an exception of consent to surgery, which was in most cases complex and usually with a certain degree of lethality. Unauthorised medical experiments were very fairly known in case law, but such were repeatedly condemned by both courts and legal scholars, with the Antiquaille Hospital Case and Chavonin to become the leading legacy on it. At the same time, it would be sound to emphasise, that all the contemporary theory of patients' rights could not exist without the old legacy, which is still under investigated, especially in Continental law.

\section{References}

-- Ārsta atbildība pēc 1933. g. sod. lik. 218. un 219. p. : Referāts /Alfrēds Jākobsons. Riga, 1936, p.p. 4-8

Boucard, C.-V. (1860). Inoculation d'accidents secondaires syphilitiques : [affaire de l'Hospice de l'Antiquaille], Lyon.

Bouisson, É.F. (1850).Traité théorique et pratique de la méthode anesthésique appliquée à la chirurgie et aux différentes branches de l'art de guerir, Paris, Libraire de l'Academie Nationale de Medecine, p. 357.

Braun Dr., prakt. (1853). Arzte zu Wiesbaden, Randbemerkungen zu dem Aufsatze: Verantwortlichkeit des Arztes bei Vornahme lebensgefährlicher Heilversuche, Henke's Zeitschrift für die Staatsarzneikunde, Bd. 66, Heft. 4, S. 417, 419-422 (1853).

Brazier, M. (1987). Patient Autonomy and Consent to Treatment: The Role of Law, 7 Legal Stud. 169, 173-178.

Demogue, R. (1932). Traité des obligations en general, Tome VI, Paris/Bibl. A. Rousseau, p. 186-187 (Ch. 1).

Deutsch, E. (1992). Das Persönlichkeitsrecht des Patienten, Archiv für die civilistische Praxis 192. Bd., H. 3, p. 165-170.

${ }^{67}$ See. Oberster Gerichtshof, Entscheidung von 17 November 1936 (Nr. 189), 3 Ob 984/36, EOG Bd. XVIII (78) S. 534, at p. $537-538$. 
Vol. 8, No. 1 Lytvynenko: The Concept of the Patient's Autonomy: From the Vaults...

Doležal, T. (2019). Právní povaha informovaného souhlasu a následky neúplného poučení z hlediska civilního práva, Časopis zdravotnického práva a bioetiky, Vol. 9 (1) p. 6165 .

Editorial - Du droit d'experimentation dans les hopitaux, La France Medicale et Pharmaceutique, 24 dec. 1859 (No. 52), p. 412.

Grassl, J. (1894). Zur Verantworlichkeit des Arztes, Friedreich's Blätter für gerichtliche Medicin und Sanitätspolizei, Bd. 22 , p. 443-450.

Guyon, J.C.F. (1873). Éléments de chirurgie clinique: comprenant le diagnostic chirurgical, les opérations en général, les méthodes opératoires, l'hygiène, le traitement des blessés et des opérés, Paris, p. 203.

Hasl, J. (1989). Patient Autonomy and the Right to Refuse Treatment: Available Remedies / Comment, 33 St. Louis U. L. J. 711, 713-714.

Jackson; D.L. \& S. Younger (1980). Patient Autonomy and Death with Dignity: Some Clinical Caveats, 20 Jurimetrics J. 348, 355-359.

K.V., Vai ārstam ir tiesība izdarīt dzīvīibu apdraudošas operācijas bez slimnieka vai vina piederīgo piekrišanas un kāda ir vina atbildība slimnieka nāves gadījumā. Jurists, Nr. 7 (01.10.1932). - Riga, 1932.

LoBiondo, A.R. (1991). Patient Autonomy and Biomedical Research: Judicial Compromise in Moore v. Regents of the University of California, 1 Alb. L. J. Sci. \& Tech. 277, 291-300.

Loughrey, J. (2005). The Confidentiality of Medical Records: Informational Autonomy, Patient Privacy, and the Law, 56 N. Ir. Legal Q. 293, 294-300; 303-306.

Lytvynenko, A.A. (2021a). The Hart-Fuller Debate on Law and Morality Within the Prism of the Legal Foundation of the Right to Privacy in its Earlier Jurisprudential Interpretations in German Case-Law, Teise Vol. 119, p. 160-169.

Lytvynenko, A.A. (2021b). The Legal Characteristics of the Patient's «Living Will»: Doctrine and Jurisprudence, 2021 (1) Medical Law 52-68,

Macdonald, V.C. (1933). Consent of patient as justification for surgical assault, The Canadian Bar Review, 1933 (No. 7, September 1933), p. 506-510.

Martin-Lauzer. A. (1860). 'Poursuites dirigées contre deux médecins à l occasion d inoculation syphilitique' in Revue de thérapeutique medico-chirurgicale: p. 23-28.

Mazure, L. (2011). Pacienta griba un tās civiltiesiskā aizsardzība: promocijas darbs. Rìga: Latvijas Universitāte, p. 28-41.

Oppenheim, L. (1892). Das ärztliche Recht zu körperlichen Eingriffen an Kranken und Gesunden, Benno Schwabe, Verlagsbuchhandlung, Basel, p. 33-38; 43-48.

Pellegrino, E.D. (1994). Patient and Physician Autonomy: Conflicting Rights and Obligations in the Physician-Patient Relationship, 10 J. Contemp. L. \& P. 47, 50

Shyriaiev, V.N. (1903). The Criminal Responsibility of Physicians, St. Petersburg, Edition of the Law Bookshop of N. K. Martynov, p. 8-14.

Steinberg, M.I. (1977). The California Natural Death Act--A Failure to Provide for Adequate Patient Safequards and Individual Autonomy, 9 Conn. L. Rev. 203, 214220

Tart, I. (1894). De la responsabilite des persones. Art du guerir. Belgique Judiciaire 1057, 1070-1072

Tregubov, S.N. (1904). The Doctor's Criminal Responsibility for Treating without the Patient's Consent, Saint Petersburg, Senate Typography, - 1, p.p. 12-19; 22-25

Velpeau, A.A.L.M. (1840). Leçons orales de clinique chirurgicale, faites à l'hôpital de la Charité. Tome 1, Paris, , p. 62

Veresaiev, V. (1901). The Doctor's Notes Ch. XVII.

von Gierke, O. (1895). Deutsches Privatenrecht Band 1: Allgemeiner Teil $u$. Personenrecht, Leipzig [u.a]., p. 703-704 


\section{Legal Instruments}

Geseß über das Heimathsrecht und das Armenwesen vom 9ten August 1833, Repertorium der Gesetz-Sammlung für das Herzogthum Altenburg: auf das Jahr 1833 (Nr.34), Nummer 1 bis Nummer 56 Art. 132 (2) / Alternburg, 1833., S. 161

Pacientu tiesību likums, Latvijas Vēstnesis, 205, 30.12.2009

Verordnung vom 16. Mai 1832, die Behandlung armer, auf der Reise begriffener Kranken betreffend, Art. 4, Codex Saronicus. Chronologische Sammlung der gesammten praktisch gültigen Königlich Sächfischen Gesetze von den älteften Seiten, vom Jahre 1255 an bis zum Schlusie des Jahres 1840; mit einem alphabetisch syftematischen Repertorium von Dr. jur. Wilhelm Michael Schaffrath. 3 weiter Band enthaltend: die gesammten Gefeße vom 9. März 1818 an bis zum Schlufie des Jahres 1840 / Leipzig, 1842, Bd. 2, S. 466-467

\section{Cases}

\section{Historical Jurisdictions}

Carl Joachim Christian Bracker, Klager, gegen Dr. Juris Albrecht, mand. nom, Oberappellationsgericht zu Lübeck, 30 Dezember 1856, Sammlung von Erkenntnissen und Entscheidungsgründen des Ober-Appellationsgerichts zu Lubeck, etc. Band 3, 1re Abteilung, Sache No. 16, S. 172 [p.p. 172 - 190] (Preußen, Freie Stadt Lübeck)

Preußische Obertribunal, Entsch. v. 15. Mai. 1872 c. Driesen (350 I. Cr.), PrObTre Str. Bd. 13, S. 307, 307-308 (Preußen)

1902 g. 19 novembra, Po delu doktora meditsyny Petra Modlinskago, 1902 Senata Kriminālā Kasācijas Departamenta Spr. N. 33, 1902 KKD p.p. 84-91 (Russian Empire)

K. K. Oberster Gerichtshof, Entsch. v. 7. Sept. 1915 Nr. 7557, Rv I 448/15, EOG Ziv. S. Bd. 52 (LII) S. 844, 845-848 (Austro-Hungarian Empire)

Nejvyšší soud Československé republiky, Rozh. ze dne 18. ledna 1927, Rv II 707/26, Váž. civ., 9 (1927), sv. 1, p. 98-100 [Č́ís. 6707] (Collection of civil cases by Dr. Prof. Jur. František Vážný, Vol. 9 (1927), Nr. 6707, at p. 98-100 (Czechoslovakian Republic)

Argentine

D., M.A. s/ Declaración de Incapacidad, Corte Suprema de Justicia de la Nacion, 7 de julio de 2015, CSJ 376/2013 (49-D).

\section{Austria}

Oberster Gerichtshof, Entscheidung von 17 November 1936 (Nr. 189), 3 Ob 984/36, EOG Bd. XVIII (78) S. 534, at p. $537-538$.

\section{Belgium}

Dechamps c. Demarche, Cour d'Appel Liege, 30 juillet 1891, Pas. 1891 II 78, 80; Sirey 1895 II 237, 237-238; Dall. Per. 1891 II 281. Demarche c. Dechamps, 27 Nov. 1889, 
Vol. 8, No. 1 Lytvynenko: The Concept of the Patient's Autonomy: From the Vaults...

Trib. civ. de Liege, Belgique Judiciaire 1890.471, Pas. 1890 III 83, 85; Journal des Tribunaux (Belge) 1890 p. 8; Jour. de. Trib. et. Rev. j. 1890.76; appeal: Dechamps c. Demarche, Cour d'Appel Liege, 30 juillet 1891, Pas. 1891 II 78, 80; Sirey 1895 II 237, 237-238; Dall. Per. 1891 II 281; Pas. 1891 II 78, 79-80.

Min. Publ. c. Fardeau, Slosse et Leclerc, Trib. corr. Bruxelles (22 ch.), 27 septembre 1969, Journal des Tribunaux Vol. 1969 (15.11.1969), No. 4676, p. 635, at p. 635-638; 639641; Pasicrisie, Vol. 1969, p. III, p.p. 114-128.

\section{Canada}

Marshall v. Curry, 1933 D.L.R. 2d. 260 (p.p. 260 -274).

\section{France}

Min. Publ. c. Guyenot et Gailleton, Trib. corr. de Lyon, 15 dec. 1859, Dall. Per. 1859 II 87, 87-88

R.... c. P...., Cour d'appel de Lyon, 27 juin 1913, Dall. Per. 1913 II 73, 73-74

Cons. Chavonin c. Dr. L..., Admin. de l'Assistance Publique et Soc. de laboratoires Thorande, Trib. civ. de la Seine (1 Chambre), 16 mai 1935, Dall. Heb. 1935.390, 390-391, Dall. Per. 1936 II 9, 13-14

L. c. Consorts Chavonin et Cie des produits chimiques de la Sorbonne, Cour d'Appel de Paris, 1 Chambre, 11 mai 1937, Dall. Hebd. 1937.340, 340-341

Chini c. Coconni, Trib. de. Aix, 22 October 1906, Dall. Per. 1907 II 41, 43;

Bours c. Consorc Prevost, Trib. de Amiens, 14 Fevr. 1906, Dall. Per. 1907 II 44, 45;

Epoux N c. Docteur Lenormant, Cour d'Appel de. Paris, 28 Juin 1923, Dall. Per. 1924 II 116, p.p. 116-117;

Vve Seignobos c. Docteur H., 31 octobre 1933, Cour de Cass., 1934 Sirey I 11, 11-12.;

Dr X c. Teyssier, 28 janvier 1942, Cour. de Cass, Cham. civ., Dall. Per. 1942 I 63.

\section{Germany}

Reichsgericht, III Strafsenat, Urt. v. 31.05.1894, Rep. 1406/94 = ERG St. S. Bd. 25. S. 375, 380-384.

OLG Bremen, 31.07.1979 - $1 \mathrm{U}$ 47/79, para. 15-et seq.

$B G H, 23.11 .1982$; VI ZR 222/79, para. 17-27; 30

\section{Latvian Republic}

1926 g. 28 sept. spr. Londenberga 1. Nr. 537, Latvijas Senata Kriminālā Kasācijas Departamenta spriedumu tezu pilnigs kopojums, no. 1919 g. lidz. 1928 g. 31 decembrim (1928) // F. Kamradziuss, p. 306-309

1928 g. 30 marta spr. Sternbergs 1. Nr. 124, 1919-1928 Kopojums, Lieta No. 592, Latvijas Senata Kriminālā Kasācijas Departamenta spriedumu tezu pilnigs kopojums, no. 1919 g. lidz. 1928 g. 31 decembrim (1928) // F. Kamradziuss, p. 311.

Ziberg pret Dr. Adamson, Riga aprinka (Sloka) Miera Tiesa, 05.06.1928, Lieta Nr. 295

Kovalenoks pret. Dr. Akerman, Riga Tiesu Palata, Kriminalnodala, 27.02.1939, Number unknown, case preservation at: LVVA, Fund Nr. 1537, Descr. 2, Case Nr. 1175

1937 g. 25 nov. / 16 dec., Vacslava Gržibovska prasībā pret Rīgas pilsētu v. c. summā Ls 14.097, Senāta Civilā kasācijas departamenta, Pašvaldības Balls, No. 7(01.07.1939); Pašvaldību Darbinieks, Nr. 4 (01.04.1939) (Case No. 10). 


\section{Poland}

Bolesław M. przeciwko Uniwersytetu Jagiellońskiego w Krakowie i dr. Mieczysław O., Sąd Najwyższy, Sygn. C.II. 885/37, Zb. Orz. 1938, z. 6, poz. 291, s. 713.

Alicja M. przeciwko Skarbu Państwa (Zespół Opieki Zdrowotnej dla miasta Częstochowa), Sąd Najwyższy, Sygn. IV CR 389/79, OSNC 1980, z. 4, s. 81.

\section{Switzerland}

In Sache des Karl Schulze, Strafgericht Kanton Basel-Stadt, Urt. v. 14.06.1882, L. Oppenheim, Das ärztliche Recht zu körperlichen Eingriffen an Kranken und Gesunden, Benno Schwabe, Verlagsbuchhandlung, Basel, 1892, p. 43-45.

\section{USA}

Salgo v. Leland Board etc. Trustees, 154 Cal. App. 2d 560, at p. 578-579 (1957) [Civ. No. 17045. First Dist. Div. One. Oct. 22, 1957].

Satz v. Perlmutter, 362 So. 2d 160, 162-164 (Fla. Dist. Ct. App. 1978); 379 So. 2d 359, 361-362 (Fla. 1980) [affirmed].

People ex rel. Yeager, 93 P. 3d 589 (Colo. Sup. Ct. 2004), at p. 593-597 (Sec. III-V). 
